\title{
心的耕耘 爱的收获
}

\author{
秦光军 \\ 丰都县名山街道中心小学校 \\ DOI:10.32629/jief.v2i5.1468
}

[摘 要] 我是一名农村小学教师, 从事班主任管理工作三十多年。我在班级管理工作摸爬滚打中, 有酸有甜, 有笑有泪。我教过的每个学生, 对老师都有着深厚的感情。究其原因我想是 “用心和学生交流”。在平时的学习、生活上关心他们, 呵护他们, 真正成为他们的朋友。尊重他 们的想法, 倾听他们的心声, 以情感的力量打开他们心灵的闸门，把全班学生紧紧地团结在自己的周围，自觉自愿地接受老师的教育。

[关键词] 爱心; 培育; 教育

中图分类号：G620 文献标识码：A

\section{1 用爱心去包容每一个孩子}

有一位教育家说过: “教育之没有爱, 犹如池塘之不能没有水。” 老 师对学生的爱是做好教育的源泉。有人说: “母爱是伟大的, 因为那是无 私的爱。” 我说: “教师的爱是博大的, 宽阔的, 它永远超过了母爱。” 因 为母爱是人的天性, 是本能的, 而老师的爱是把母爱和师爱融为一体, 它是无私的, 宽容的。它不因哪位学生有了缺点或者犯了错误而抹繁了, 也不因哪一位学生的家庭或学习好而倍受青睬, 更不因哪一位同学是后 进生而另眼看待。比如: 上期我班有一名男孩叫朱丙印, 父母离异, 母 亲带着他和妹妹一起生活, 母亲紧靠种菜、卖菜维持家庭生活和供他和 妹妹上学, 家庭非常困难。他很懂事, 经常帮助妈妈做家务。他学习成 绩差而且性格非常内向。我了解情况后就利用课余时间给他补课, 找他 谈心, 给他更多的温暖和爱护。平时, 我掏钱给他买学习用品, 给订阅 课外读物……课堂上经常提问他, 发现他的闪光点给予表扬。在我的呵 护下, 成绩提高了, 学习有了信心, 爱发言了。由于棚户改造搬家到新 县城, 转学到融智学校读书。临走时, 他哭着说 “老师, 我真舍不得你”, 就这样简单的、发自内心的一句话, 我感到老师付出的爱心得到了回报。

\section{2 用爱心去呵护每一个孩子}

俗话说: “尺有所短, 寸有所长”。十个指头还分长短, 何况是一个个 活生生的、性格各异、智力差异的人, 需要我们老师用爱心去呵护每一个 孩子。“爱” 是教育的核心, 也是教师职业道德的核心。教师对学生的爱 表现在亲近、理解、关心、体贴上。我们要怀着炽热的情感, 慈母的心肠, 真心实意地从生活上、学习上关心、呵护每一位学生。比如: 2016 年春, 我班一个叫郎锐的孩子身患白血病, 在号召全班同学捐款时, 我主动捐款 500 元, 并且带着学生代表亲自到家关心病情; 又如: 平时学生生病, 亲 自带到医院主动拿钱给学生看病。主动掏钱为孩子们复印学习资料等。

班主任既要做良师, 又要做慈母。有人把班主任比作鸡妈妈, 全心 全意呵护着鸡宝宝。的确是啊, 现在, 学生只要有什么事都找老师帮 忙……孩子常说: “我们班主任眼真尖, 什么事都逃不过他的眼睛”。

\section{3 用耐心去教育每一位学生}

班主任对待每一位学生要有十足地耐心, 不仅在讲解知识时要有耐 心, 而且对学生进行思想教育时也要有耐心, 真正做到诲人不倦。学生 行为习惯、学习习惯、安全教育等方面, 不是老师说讲一次学生就能做 到。我们老师要利用班会、晨会、放学等时间对学生进行不厌其烦的教 育, 做到时时讲、天天讲, 月月讲, 就这样经常讲, 学生难免还会犯错。 如: 我班有一名学生李强, 父母离异, 家里没有人照管他, 逐渐养成了 小偷小摸的坏习惯。有一次, 他偷了班里同学的钱, 我没有大声训斥他,
而是举例子, 讲道理, 真是 “晓之以理, 动之以情”。当时他向我保证, 再也不偷了。我相信了他, 真的觉得他会改好。可是, 出乎我意外。有 一天, 他向我请假不做课间操, 结果, 他在教室把所有同学的书包翻了 个遍。我知道后, 真的觉得这个孩子无药可救了。我转念一想: 大人养 成了坏习惯, 让他一下子改好都很难, 何况他还是一个孩子。我没有批 评他, 通过几天的观察, 发现他热爱劳动。我把他叫到办公室, 对他说: “老师知道你也有优点, 爱劳动”。他听了我的话, 低下了头。从此, 我 发现了他的闪光点就及时表扬, 在我不断的鼓励下, 他再也没有偷过, 还被同学们选为清洁委员。从这里, 我体会到对全班同学的教育要有耐 心, 对每一个学生的教育也要有耐心。

\section{4 用公正心来对待每一个学生}

当一名法官, 最重要的是有一颗公正的心, 真正做到 “认理不认亲”。 而当一名班主任, 也要做到公正无私。无论是对待品学兼优的学生, 还 是 “双差生” 都得一视同仁, 不能因为是品学兼优的学生犯了错就可以 原谅, 也不能因为是双差生, 就什么错误都推给他, 一棍子打死, 有一 件事就深深地触动了我, 至今还记忆犹新。有一次, 我班的李亮和班长 杨明不知为什么打了起来, 而且打得很凶。他们俩被叫到办公室, 李亮 是我们班出了 “打仗大王”。开始, 我就认定是他的错, 不问青红㿝白, 狠狠地批评了李亮, 没有给他申辩的机会。李亮当时就表现出很不服气 的样子, 他双手紧握着拳头, 狠狠地瞪了我一眼, 从牙缝里挤出几个字 “当老师的都是偏心眼儿。” 说完, 就冲出了办公室。这时, 我呆住了, 心想: 怎么, 难道我冤枉了他? 于是, 我调查事情的前因后果, 原来是 班长杨明给李亮起绰号才引起这场 “战争”。我当着全班同学的面向李亮 同学道了㭲, 批评了班长杨明。刚才受到批评时都没有掉眼泪, 这时却 流下了眼泪, 还抽噎着说: “老师, 也有错误”。听了他的话, 我的心里 思绪万千。如果我不澄清事实, 那么在这个孩子心里会造成多大的误解, 多大的伤害啊! 孩子的心是一面镜子, 容不得老师有半点偏私。我们当 班主任的, 时刻应该记住: 要有一颗公正心来对待每一个孩子。

总之, 我们班主任老师要用爱心去包容和呵护每一个孩子, 要用耐 心和公正心来对待每一个孩子。

\section{[参考文献]}

[1]桝燨.怎样做一个有爱心的教师[J]. 文学教育(下),2020(08):183.

[2]王石川。用爱心点亮山里孩子的梦想 [N]. 贵州日 报,2020-08-12(005).

[3]魏强安. 爱心浇灌耐心培育——我的班主任工作漫谈[J].科学 咨询(科技・管理),2020(08):208. 